Buana Sains Vol 18 No 1: 11 - 20, 2018

\title{
PENGARUH KOMPOS AMPAS SAGU DAN PLANT GROWTH PROMOTION RHIZOBACTERIA (PGPR) TERHADAP PERTUMBUHANDAN HASIL KACANG TANAH (Arachis hypogeal L.)
}

\section{Saerah Adam, Mochamad Dawam Magfoer dan Didik Haryono}

Program Pascasarjana Universitas Brawijaya Malang

\begin{abstract}
The aims of this research is to find out the influence of the application of sago waste compost and PGPR on the increase in groundnut growth and yield and to obtain the dose of sago waste compost and PGPR concentration that able to increase the growth and yield of groundnut had been conducted in January to March 2016 in Maba Sangaji Village, Kota Maba Subdistrict, East Halmahera Regency. The research used factorial randomized complete block design consisting of two factors with three replication. Factor I was the dose of sago waste compost consisted of four levels: $\mathrm{K} 0=$ without sago waste compost (control), $\mathrm{K} 1=$ sago waste compost of $10 \mathrm{t} \mathrm{ha}^{-1}, \mathrm{~K} 2=$ sago waste compost of $15 \mathrm{t} \mathrm{ha}^{-1}$, and $\mathrm{K} 3=$ sago waste compost of $20 \mathrm{t} \mathrm{ha}^{-1}$. Factor II was concentration of Plant Growth Promoting Rhizobacteria (PGPR) consisted of 4 levels: P0 = without PGPR (control), P1 = PGPR of $5 \mathrm{ml} \mathrm{l}^{-1}, \mathrm{P} 2=$ PGPR of $10 \mathrm{ml} \mathrm{l}^{-1}$, and P3 $=$ PGPR of $15 \mathrm{ml} \mathrm{l}^{-1}$. The observation consisted of growth components of plant height, the number of leaves, leaf area, crop dry weight, and crop growth rate, and yield components of the number of pods, filled pods, empty pods, pod weight, grain weight, and weight of 100 grain. Research result shows that there was no interaction between the treatment of sago waste compost and PGPR. However, separately, treatments of sago waste compost and PGPR had the significant influence on the growth and yield of groundnut. The highest groundnut yield was obtained in the treatment of sago waste compost with the dose of $20 \mathrm{t} \mathrm{ha}^{-1}$. Grain weight obtained was $17.51 \mathrm{~g}$ or an increase of $52.15 \%$ compared to those of treatment without application of sago waste compost and yield of grain weight per hectare was $2.80 \mathrm{t} \mathrm{ha}^{-1}$. The inoculation of PGPR increased the growth and yield of groundnut. The application of PGPR with the concentration of 10 and $15 \mathrm{ml}^{-1}$ produced better crop growth. The higher result was obtained in the treatment of PGPR with the concentration of 10 and $15 \mathrm{ml} \mathrm{l}^{-1}$ with grain weight of 15.46 $\mathrm{g}$ and $16.81 \mathrm{~g}$ plant- 1 or an increase of $31.15 \%$ and $42.6 \%$, respectively, compared to control,whereas, grain weight per hectare was $2.47 \mathrm{t} \mathrm{ha}^{-1}$ and $2.69 \mathrm{t} \mathrm{ha}^{-1}$, respectively.
\end{abstract}

Keywords: Ground nut; dry land; sago waste compost; PGPR

\section{Pendahuluan}

Kacang tanah (Arachis bypogaea L.) merupakan komoditas strategis sebagai sumber bahan makanan pokok dan berperan dalam meningkatkan pendapatan dan kesejahteraan petani. Komoditas kacang tanah memiliki peran yang cukup besar terutama untuk memenuhi kebutuhan protein, bahan baku industri pangan olahan dan pakan selain kedelai. 
S. Adam, M. D.Magfoer dan D.Haryono/ Buana Sains Vol 18 No 1 : 11-20

Salah satu penyebab rendahnya produktivitas kacang tanah ialah pengelolaan hara yang tidak sesuai. Menurut Veeramani et al. (2012), kebanyakan petani kacang tanah, terutama pada daerah kering mengaplikasikan pupuk dalam jumlah yang sedikit dan terkadang hanya memupuk dengan satu atau dua unsur saja sehingga mengakibatkan tanaman tidak mendapatkan unsur hara dalam jumlah yang cukup. Kebutuhan unsur hara yang tidak mencukupi dan unsur hara yang tidak seimbang mengakibatkan produktivitas tanaman kacang tanah menjadi rendah. Salah satu sumber bahan organik di Provinsi Maluku Utara yang dapat dimanfaatkan sebagai pupuk organik ialah ela sagu atau ampas sagu. Selain itu, pemanfaatan ampas sagu sebagai kompos akan mengurangi penumpukan limbah organik dan bermanfaat untuk menyediakan unsur hara serta memperbaiki sifat tanah (Zaimah dan Prihastanti, 2012).

Penggunaan pupuk hayati pada budidaya kacang tanah dimaksudkan untuk membantu menyediakan unsur hara $\mathrm{N}$ dan atau $\mathrm{P}$ bagi tanaman, tanpa terjadi residu kimia pada lingkungan, di samping juga untuk meningkatkan populasi mikrob di daerah perakaran tanaman (Prihastuti, 2007). Pemanfaatan pupuk kompos ampas sagu dan PGPR serta efektivitasnya pada kacang tanah di daerah kering masih belum banyak diketahui. Oleh karenanya diperlukan upaya untuk mempelajari pengaruh pupuk ampas kompos sagu dan PGPR pada kacang tanah di lahan kering. Penelitian ini bertujuan untuk 1) mendapatkan interaksi antara perlakuan kompos ampas sagu dan PGPR terhadap pertumbuhan dan hasil kacang tanah, 2) mendapatkan dosis kompos ampas sagu yang dapat meningkatkan pertumbuhan dan hasil kacang tanah dan 3) mendapatkan konsentrasi PGPR yang dapat meningkatkan pertumbuhan dan hasil kacang tanah.

\section{Metode Penelitian}

Penelitian dilaksanakan di Desa Maba Sangaji Kecamatan Kota Maba Kabupaten Halmahera Timur. Lokasi penelitian mempunyai suhu rata-rata 24 $32^{\circ} \mathrm{C}$ dan kelembaban $60-95 \%$. Penelitian dilaksanakan mulai bulan Januari sampai dengan bulan Mei 2016. Penelitian dilaksanakan dengan menggunakan Rancangan Acak Kelompok (RAK) faktorial yang terdiri atas 2 faktor serta diulang 3 kali. Faktor I adalah dosis kompos ampas sagu yang terdiri atas 4 taraf yaitu : $\mathrm{K}_{0}=$ Tanpa Kompos ampas sagu (kontrol), $K_{1}=$ Kompos Ampas Sagu $10 \mathrm{t} \mathrm{ha}^{-1}, \mathrm{~K}_{2}=$ Kompos Ampas Sagu $15 \mathrm{t} \mathrm{ha}^{-1}, \mathrm{~K}_{3}=$ Kompos Ampas Sagu $20 \mathrm{t}$ ha $^{-1}$. Faktor II adalah konsentrasi Plant Growth Promoting Rhizobacteria (PGPR) yang terdiri atas 4 taraf yaitu : $\mathrm{P}_{0}=$ Tanpa PGPR (kontrol), $\mathrm{P}_{1}=$ PGPR $5 \mathrm{ml} \mathrm{l}^{-1}, \mathrm{P}_{2}=$ PGPR $10 \mathrm{ml}$ $\mathrm{l}^{-1}, \mathrm{P}_{3}=$ PGPR $15 \mathrm{ml} \mathrm{l}^{-1}$. Aplikasi kompos ampas sagu diberikan satu minggu sebelum penanaman. PGPR diberikan sebanyak 3 kali dengan tahapan sebagai berikut 1) dilakukan dengan cara merendam benih dengan larutan PGPR dengan konsentrasi sesuai perlakuan masing-masing selama 10 menit sebelum penanaman, 2) dilakukan dengan perlakuan yang sama pada 2 MST dan 4 MST (Kacang tanah mulai berbunga) dengan konsentrasi sesuai perlakuan sebagaimana pada tahap satu. Penanaman dilakukan dengan membuat lubang tanam sedalam $3 \mathrm{~cm}$, menggunakan tugal dengan jarak tanam $20 \times 25 \mathrm{~cm}$. Setiap lubang tanam ditanami benih sebanyak 2 butir dan ditutup dengan tanah tipis-tipis. Penjarangan tanaman dilakukan 10 hari setelah tanam dengan meninggalkan 1 
S. Adam, M. D.Magfoer dan D.Haryono/ Buana Sains Vol 18 No 1 : 11-20

tanaman yang sehat untuk dipelihara. Pengamatan meliputi komponen pertumbuhan yaitu : tinggi tanaman, jumlah daun, luas daun, berat kering tanaman, dan laju tumbuh tanaman yang dilakukan pada umur 4,6,8,10, dan 12 MST, serta pengamatan komponen hasil yaitu jumlah polong, polong isi, polong hampa, bobot polong, bobot biji, bobot 100 biji yang dilakukan pada saat panen.

Data yang dikumpulkan dianalisis dengan menggunakan analisis keragaman. Apabila dari hasil analisis ragam terdapat pengaruh perbedaan yang nyata di antara perlakuan yang diteliti maka dilakukan uji lanjut dengan uji BNT 5\%.

\section{Hasil dan Pembahasan}

\section{Komponen Pertumbuhan}

Perlakuan pupuk kompos ampas sagu dapat meningkatkan pertumbuhan tanaman kacang tanah. Pada Tabel 1, 2, dan 3 menunjukkan bahwa tanaman kacang tanah yang dipupuk dengan pupuk kompos ampas sagu mempunyai tinggi tanaman, jumlah daun, luas daun dan berat kering tanaman kacang tanah lebih tinggi dibandingkan tanpa aplikasi pupuk kompos ampas sagu dari awal pengamatan umur 4 MST sampai 12 MST.

Peningkatan pertumbuhan tanaman kacang tanah dari awal pertumbuhan sebagai akibat perlakuan pupuk kompos ampas sagu diduga karena pemberian pupuk kompos ampas sagu mampu menyediakan unsur hara bagi tanaman. Pupuk kompos ampas sagu yang dipergunakan mempunyai nilai C/N 11,87 yang termasuk kategori sedang, sehingga mudah terdekomposisi dan cepat menyediakan hara bagi tanaman. Nisbah $\mathrm{C} / \mathrm{N}$ sangat menentukan laju dekomposisi bahan organik, dimana bahan organik yang mempunyai nisbah $\mathrm{C} / \mathrm{N}$ rendah lebih cepat terdekomposisi dibandingkan bahan organik yang memiliki nisbah $\mathrm{C} / \mathrm{N}$ tinggi (Sabran et al., 2015). Ketersediaan hara yang cukup sejak awal pertumbuhan dan selama siklus hidup tanaman kacang tanah akan berpengaruh besar pada pertumbuhan dan hasil tanaman.

Tabel 1. Rata-rata tinggi kacang tanah $(\mathrm{cm})$ akibat pengaruh pupuk kompos ampas sagu dan PGPR pada berbagai umur pengamatan

\begin{tabular}{|c|c|c|c|c|c|}
\hline \multirow[t]{2}{*}{ Perlakuan } & \multicolumn{5}{|c|}{ Umur Pengamatan (MST) } \\
\hline & 4 & 6 & 8 & 10 & 12 \\
\hline \multicolumn{6}{|c|}{ Kompos ampas sagu } \\
\hline $\mathrm{K}_{0}$ (kontrol) & $17,28 \mathrm{a}$ & $26,84 \mathrm{a}$ & $34.98 \mathrm{a}$ & $40,71 \mathrm{a}$ & $52,59 \mathrm{a}$ \\
\hline $\mathrm{K}_{1}\left(10 \mathrm{tha}^{-1}\right)$ & $18.27 \mathrm{a}$ & $28,36 \mathrm{ab}$ & $37,58 \mathrm{ab}$ & $42,96 \mathrm{ab}$ & $55,38 \mathrm{ab}$ \\
\hline $\mathrm{K}_{2}\left(15 \mathrm{tha}^{-1}\right)$ & $19,35 \mathrm{ab}$ & $30,80 \mathrm{bc}$ & $39,10 \mathrm{bc}$ & $44,58 \mathrm{bc}$ & $57,38 \mathrm{bc}$ \\
\hline $\mathrm{K}_{3}\left(20 \mathrm{tha}^{-1}\right)$ & $20,63 \mathrm{~b}$ & $33,42 \mathrm{c}$ & $41,11 \mathrm{c}$ & $47,56 \mathrm{c}$ & $61,36 \mathrm{c}$ \\
\hline BNT 5\% & 2,10 & 2,83 & 3,16 & 3,38 & 4,46 \\
\hline \multicolumn{6}{|c|}{ Konsentrasi PGPR } \\
\hline $\mathrm{P}_{0}$ (kontrol) & $16,65 \mathrm{a}$ & $26,38 \mathrm{a}$ & $35,94 \mathrm{a}$ & $41,04 \mathrm{a}$ & $53,67 \mathrm{a}$ \\
\hline $\mathrm{P}_{1}\left(5 \mathrm{ml} \mathrm{l}^{-1}\right)$ & $18,31 \mathrm{ab}$ & $29,50 \mathrm{~b}$ & $37,33 \mathrm{a}$ & $43,44 \mathrm{ab}$ & $55,06 \mathrm{a}$ \\
\hline $\mathrm{P}_{2}\left(10 \mathrm{ml} \mathrm{l}^{-1}\right)$ & $19,65 \mathrm{bc}$ & $30,83 \mathrm{bc}$ & $38,90 \mathrm{ab}$ & $44,54 \mathrm{bc}$ & $57,84 \mathrm{ab}$ \\
\hline $\mathrm{P}_{3}\left(15 \mathrm{ml} \mathrm{l}^{-1}\right)$ & $20,92 \mathrm{c}$ & $32,72 \mathrm{c}$ & $40,61 \mathrm{~b}$ & $46,79 \mathrm{c}$ & $60,13 \mathrm{~b}$ \\
\hline BNT 5\% & 2,10 & 2,83 & 3,16 & 3,38 & 4,46 \\
\hline
\end{tabular}

Keterangan : Bilangan pada kolom yang sama dan didampingi dengan huruf yang sama pula menunjukkan tidak berbeda nyata pada uji BNT 5\% 
Peningkatan pada pertumbuhan tanaman kacang tanah dipengaruhi oleh dosis pupuk kompos ampas sagu. Hal tersebut sesuai dengan penjelasan Marsono dan Sigit (2000), bahwa pemberian pupuk dengan dosis yang tepat berperan penting dalam meningkatkan ketersediaan unsur hara di dalam tanah, yang pada akhirnya akan mempengaruhi tingkat pertumbuhan dan produksi tanaman. Hasil penelitian menunjukkan bahwa dosis pupuk kompos ampas sagu yang diberikan berpengaruh nyata pada pertumbuhan tanaman kacang tanah dari awal pengamatan yaitu 4 MST sampai 12 MST. Perlakuan pupuk kompos ampas sagu dengan dosis 10 ton $\mathrm{ha}^{-1}\left(\mathrm{~K}_{1}\right)$ menghasilkan pertumbuhan tanaman lebih rendah dibandingkan dosis 15 dan $20 \mathrm{t} \mathrm{ha}^{-1}\left(\mathrm{~K}_{2}\right.$ dan $\left.\mathrm{K}_{3}\right)$. Hal tersebut diduga karena peningkatan dosis pupuk kompos ampas sagu semakin meningkatkan ketersediaan unsur hara dalam tanah sehingga ketersediaan hara bagi tanaman kacang tanah menjadi meningkat. Ketersediaan unsur hara dalam jumlah yang cukup dan seimbang merupakan faktor utama dalam pertumbuhan tanaman kacang tanah. Hasil analisis pupuk kompos ampas sagu mengandung C-organik sebesar 15,8\% (tinggi sekali), $\mathrm{N}$ total 1,03\% (tinggi sekali), P 0,24\% (rendah sekali) dan $\mathrm{K} 0,42 \%$ (sedang), sehingga untuk dapat memenuhi kebutuhan hara tanaman kacang tanah maka harus diberikan dalam jumlah yang cukup besar. Untuk dapat tumbuh dengan baik tanaman kacang tanah membutuhkan $\mathrm{N}$ yang relatif lebih besar dari pada unsur hara lainnya. Meskipun demikian tanaman kacang tanah juga memerlukan fosfor dan kalsium serta unsur hara lainnya untuk pembentukan biji. Sementara pada pertumbuhan, ketersediaan $\mathrm{P}$ diperlukan untuk membentuk sistem perakaran yang baik. Kebutuhan unsur P pada tanaman kacang-kacangan yang membentuk bintil akar lebih besar dibandingkan yang tidak membentuk bintil akar. Kekurangan $\mathrm{P}$ akan menghambat fiksasi $\mathrm{N}$ dan interaksi simbiosis. Kebutuhan P pada tanaman kacang-kacangan menjadi lebih tinggi dibandingkan pada dengan tanaman non kacang-kacangan karena berperan penting dalam pembentukan nodul dan fiksasi nitrogen atmosfer (Kabir et al., 2013).

Peningkatan dosis pupuk kompos ampas sagu meningkatkan ketersediaan unsur hara untuk tanaman kacang tanah. Pupuk kompos ampas sagu mengandung unsur hara makro dan mikro dalam jumlah yang lebih rendah dibandingkan pupuk anorganik dan mempunyai sifat pelepasan hara yang perlahan. Oleh karenanya untuk dapat memenuhi kebutuhan hara bagi tanaman diperlukan aplikasi pupuk dalam jumlah yang banyak, sehingga peningkatan dosis pupuk dari 10 menjadi $20 \mathrm{t} \mathrm{ha}^{-1}$ semakin meningkatkan pertumbuhan tanaman. Hasil analisis tanah sesudah penelitian menunjukkan bahwa peningkatan dosis pupuk kompos pada ampas sagu dapat meningkatkan ketersediaan unsur hara $\mathrm{P}$ dan $\mathrm{K}$ pada tanah, sementara pada unsur $\mathrm{N}$ tidak terjadi peningkatan dalam tanah. Menurut Utami dan Handayani (2003), penambahan pupuk $\mathrm{N}$ dalam tanah tidak mesti diikuti peningkatan kandungan $\mathrm{N}$ total dalam tanah, karena unsur $\mathrm{N}$ banyak yang hilang terangkut hasil panen, atau melalui pelindian dan penguapan. Peningkatan ketersediaan unsur hara $\mathrm{N}$, $\mathrm{P}$ dan $\mathrm{K}$ dalam tanah akibat peningkatan dosis pupuk kompos ampas sagu semakin meningkatkan pertumbuhan tanaman. Hal tersebut dapat dilihat pada Tabel 1, 2 dan 3 dimana setiap peningkatan dosis pupuk ampas sagu semakin meningkatkan tinggi tanaman, jumlah daun, luas daun dan berat kering tanaman kacang tanah. 
S. Adam, M. D.Magfoer dan D.Haryono/ Buana Sains Vol 18 No 1 : 11-20

Tabel 2. Rata-rata jumlah daun kacang tanah (helai) akibat pengaruh pupuk kompos ampas sagu dan PGPR pada berbagai umur pengamatan

\begin{tabular}{|c|c|c|c|c|c|}
\hline \multirow[t]{2}{*}{ Perlakuan } & \multicolumn{5}{|c|}{ Umur Pengamatan (MST) } \\
\hline & 4 & 6 & 8 & 10 & 12 \\
\hline \multicolumn{6}{|l|}{ Kompos ampas sagu } \\
\hline $\mathrm{K}_{0}$ (kontrol) & 17,18 a & $41,00 \mathrm{a}$ & $74,52 \mathrm{a}$ & $107,75 \mathrm{a}$ & $88,54 \mathrm{a}$ \\
\hline $\mathrm{K}_{1}\left(10 \mathrm{tha}^{-1}\right)$ & 18,07 a & $43,47 \mathrm{ab}$ & $79,65 \mathrm{ab}$ & $115,42 \mathrm{ab}$ & $91,15 \mathrm{a}$ \\
\hline $\mathrm{K}_{2}\left(15 \mathrm{tha}^{-1}\right)$ & $20,55 \mathrm{~b}$ & $46,35 \mathrm{bc}$ & $81,04 \mathrm{~b}$ & $123,17 \mathrm{bc}$ & $96,00 \mathrm{ab}$ \\
\hline $\mathrm{K}_{3}\left(20 \mathrm{t} \mathrm{ha}^{-1}\right)$ & $21,68 \mathrm{~b}$ & $49,90 \mathrm{c}$ & $83,45 \mathrm{~b}$ & $131,60 \mathrm{c}$ & $103,58 \mathrm{~b}$ \\
\hline BNT 5\% & 1,92 & 3,61 & 5,59 & 11,22 & 8,24 \\
\hline \multicolumn{6}{|l|}{ Konsentrasi PGPR } \\
\hline $\mathrm{P}_{0}$ (kontrol) & $17,81 \mathrm{a}$ & $41,65 \mathrm{a}$ & $75,17 \mathrm{a}$ & $104,71 \mathrm{a}$ & $87,19 \mathrm{a}$ \\
\hline $\mathrm{P}_{1}\left(5 \mathrm{ml} \mathrm{l}^{-1}\right)$ & $18,75 \mathrm{ab}$ & $43,81 \mathrm{ab}$ & $78,08 \mathrm{ab}$ & $119,46 \mathrm{~b}$ & $92,88 \mathrm{ab}$ \\
\hline $\mathrm{P}_{2}\left(10 \mathrm{ml} \mathrm{l}^{-1}\right)$ & $19,93 \mathrm{bc}$ & $46,76 \mathrm{bc}$ & 81,08 bc & $122,44 \mathrm{bc}$ & $97,02 \mathrm{bc}$ \\
\hline $\mathrm{P}_{3}\left(15 \mathrm{ml} \mathrm{l}^{-1}\right)$ & $20,98 \mathrm{c}$ & $48,50 \mathrm{c}$ & $84,32 \mathrm{c}$ & $131,33 \mathrm{c}$ & $102,19 \mathrm{c}$ \\
\hline BNT 5\% & 1,92 & 3,61 & 5,59 & 11,22 & 8,24 \\
\hline
\end{tabular}

Keterangan : Bilangan pada kolom yang sama dan didampingi dengan huruf yang sama pula menunjukkan tidak berbeda nyata pada uji BNT 5\%.

Hasil penelitian menunjukkan, perlakuan PGPR berpengaruh nyata meningkatkan pertumbuhan tanaman kacang tanah. Tabel 1, 2, dan 3 menunjukkan bahwa pemberian PGPR meningkatkan tinggi tanaman, jumlah daun, luas daun dan berat kering tanaman kacang tanah. Peningkatan konsentrasi PGPR dari $5 \mathrm{ml} \mathrm{l}^{-1}\left(\mathrm{~K}_{1}\right)$ menjadi $15 \quad \mathrm{ml}^{-1} \quad\left(\mathrm{~K}_{3}\right)$ semakin meningkatkan pertumbuhan tanaman kacang tanah. Pertumbuhan tanaman lebih baik diperoleh melalui aplikasi PGPR dengan konsentrasi $10 \mathrm{ml} \mathrm{l}^{-1}\left(\mathrm{~K}_{2}\right)$ dan $15 \mathrm{ml} \mathrm{l}^{-1}\left(\mathrm{~K}_{3}\right)$. PGPR mengandung bakteri pelarut fosfat dan bakteri fiksasi $\mathrm{N}$, sehingga peningkatan konsentrasi PGPR pada tanaman dapat semakin meningkatkan ketersediaan hara $\mathrm{N}$ dan $\mathrm{P}$ bagi tanaman kacang tanah. Pada dasarnya inokulasi bakteri ditujukan untuk meningkatkan jumlah bintil akar sehingga akan meningkatkan fiksasi nitrogen. Nodulasi, fiksasi $\mathrm{N}_{2}$ dan aktifitas nodul berkaitan dengan ketersediaan P. Fosfor diperlukan untuk pertumbuhan sistem perakaran yang baik dan nodulasi yang berlimpah, sehingga dapat meningkatkan fiksasi $\mathrm{N}_{2}$ (Badar et al., 2015). Fosfor terlibat dalam berbagai proses kimia dan molekuler terutama dalam pembentukan dan pemanfaatan energi pada tanaman (Epstein dan Bloom, 2005), serta dapat mempercepat pembungaan dan pemasakan polong (Raja 2013). Kebutuhan unsur P pada tanaman kacang-kacangan yang membentuk bintil akar lebih besar dibandingkan yang tidak membentuk bintil akar.

Konsentrasi PGPR berpengaruh nyata pada peningkatan pertumbuhan tanaman kacang tanah. Pada Tabel 1,2 dan 3 dapat diketahui bahwa setiap konsentrasi menghasilkan tinggi, jumlah daun, luas daun dan berat yang berbeda. Perlakuan PGPR dengan konsentrasi 5 $\mathrm{ml} \mathrm{l}^{-1}\left(\mathrm{P}_{1}\right)$ menghasilkan tinggi tanaman, jumlah daun, luas daun dan berat kering lebih rendah dibandingkan konsentrasi 10 dan $15 \mathrm{ml} \mathrm{l}^{-1}\left(\mathrm{P}_{2}\right.$ dan $\left.\mathrm{P}_{3}\right)$. Peningkatan konsentrasi PGPR dari $5 \mathrm{ml} \mathrm{l}^{-1}$ menjadi $15 \mathrm{ml} \mathrm{l}^{-1}$ mengakibatkan semakin banyak mikroorganisme yang ditambahkan ke dalam tanah. 
S. Adam, M. D.Magfoer dan D.Haryono/ Buana Sains Vol 18 No 1 : 11-20

Tabel 3. Rata-rata bobot kering tanaman kacang tanah (g/tan.) akibat pengaruh pupuk kompos ampas sagu dan PGPR pada berbagai umur pengamatan

\begin{tabular}{lccccc}
\hline Perlakuan & \multicolumn{5}{c}{ Umur Pengamatan (MST) } \\
\cline { 2 - 6 } & 4 & 6 & 8 & 10 & 12 \\
\hline Kompos ampas sagu & $5,96 \mathrm{a}$ & $16,51 \mathrm{a}$ & $24,25 \mathrm{a}$ & $30,44 \mathrm{a}$ & $38,47 \mathrm{a}$ \\
$\mathrm{K}_{0}($ kontrol) & $6,83 \mathrm{ab}$ & $18,20 \mathrm{ab}$ & $27,47 \mathrm{~b}$ & $34,65 \mathrm{~b}$ & $42,93 \mathrm{~b}$ \\
$\mathrm{~K}_{1}\left(10 \mathrm{t} \mathrm{ha}^{-1}\right)$ & $7,39 \mathrm{bc}$ & $19,63 \mathrm{bc}$ & $29,18 \mathrm{bc}$ & $36,77 \mathrm{bc}$ & $45,86 \mathrm{bc}$ \\
$\mathrm{K}_{2}\left(15 \mathrm{t} \mathrm{ha}^{-1}\right)$ & $7,86 \mathrm{c}$ & $20,71 \mathrm{c}$ & $30,64 \mathrm{c}$ & $38,81 \mathrm{c}$ & $48,36 \mathrm{c}$ \\
$\mathrm{K}_{3}\left(20 \mathrm{t} \mathrm{ha}^{-1}\right)$ & 0,89 & 1,87 & 2,52 & 3,01 & 3,34 \\
\hline BNT $\%$ & & & & & \\
\hline Konsentrasi PGPR & $6,03 \mathrm{a}$ & $16,93 \mathrm{a}$ & $25,55 \mathrm{a}$ & $32,10 \mathrm{a}$ & $40,26 \mathrm{a}$ \\
$\mathrm{P}_{0}\left(\right.$ kontrol$\left.^{\circ}\right)$ & $6,54 \mathrm{ab}$ & $17,98 \mathrm{ab}$ & $26,94 \mathrm{ab}$ & $33,95 \mathrm{ab}$ & $42,33 \mathrm{ab}$ \\
$\mathrm{P}_{1}\left(5 \mathrm{ml} \mathrm{l}^{-1}\right)$ & $7,42 \mathrm{bc}$ & $19,45 \mathrm{bc}$ & $28,81 \mathrm{bc}$ & $36,32 \mathrm{bc}$ & $45,32 \mathrm{bc}$ \\
$\mathrm{P}_{2}\left(10 \mathrm{ml} \mathrm{l}^{-1}\right)$ & $8,05 \mathrm{c}$ & $20,68 \mathrm{c}$ & $30,25 \mathrm{c}$ & $38,30 \mathrm{c}$ & $47,70 \mathrm{c}$ \\
$\mathrm{P}_{3}\left(15 \mathrm{ml} \mathrm{l}^{-1}\right)$ & 0,89 & 1,87 & 2,52 & 3,01 & 3,34 \\
\hline BNT $5 \%$ & &
\end{tabular}

Keterangan : Bilangan pada kolom yang sama dan didampingi dengan huruf yang sama pula menunjukkan tidak berbeda nyata pada uji BNT 5\%.

Peningkatan mikroorganisme yang menguntungkan berupa bakteri fiksasi $\mathrm{N}$ dan pelarut fosfat akan meningkatkan ketersediaan unsur hara bagi tanaman kacang tanah yang ditanam pada lahan kering. Hasil analisa tanah sesudah penelitian menunjukkan terjadi kenaikan P-tersedia sebagai akibat perlakuan PGPR pada tanah. Rahni dan Karimuna (2014) menjelaskan, peningkatan serapan $\mathrm{N}$ dipengaruhi oleh kandungan mikroba penambat N (Azospirillum dan Azotobacter) di dalam pupuk tersebut, baik melalui mekanisme biotik dan non simbiotik, sedangkan penyerapan $\mathrm{P}$ berhubungan erat dengan proses metabolisme. Hal tersebut sesuai dengan hasil penelitian People et al. (1995 dalam Singh et al., 2011) yang melaporkan bahwa pupuk hayati meningkatkan kelarutan dan ketersediaan $\mathrm{N}$ di rbizosphore serta pemanjangan ruas. Peningkatan pembelahan dan pemanjangan sel meningkatkan tinggi tanaman dan jumlah daun sehingga meningkatkan area fotosintesis dan pada akhirnya meningkatkan hasil tanaman.

\section{Komponen Hasil}

Perlakuan pupuk kompos ampas sagu pada tanaman kacang tanah dapat meningkatkan jumlah polong isi dan total polong per tanaman, serta menurunkan jumlah polong hampa per tanaman. Pada Tabel 4 menunjukkan bahwa perlakuan kompos ampas sagu sebanyak $10 \mathrm{t} \mathrm{ha}^{-1}$ $\left(\mathrm{K}_{1}\right)$ menghasilkan jumlah polong isi lebih rendah dan polong hampa lebih tinggi dibandingkan dosis pupuk kompos ampas sagu yang lebih tinggi. Peningkatan dosis pupuk kompos ampas sagu menjadi $20 \mathrm{t} \mathrm{ha}^{-1}\left(\mathrm{~K}_{3}\right)$ menghasilkan jumlah polong isi menjadi lebih tinggi dan menurunkan jumlah polong hampa lebih rendah, meskipun tidak berbeda nyata dengan dosis $15 \mathrm{t} \mathrm{ha}^{-1}\left(\mathrm{~K}_{2}\right)$. Tanaman kacang tanah yang ditanam pada tanah yang tidak diberikan pupuk kompos ampas sagu mempunyai jumlah polong isi lebih rendah serta polong hampa lebih tinggi, meskipun demikian tidak berbeda nyata dengan tanaman yang diaplikasikan pupuk kompos ampas sagu sebesar 10 t ha $^{-1}\left(K_{1}\right)$. 
S. Adam, M. D.Magfoer dan D.Haryono/ Buana Sains Vol 18 No 1 : 11-20

Tabel 4. Rata-rata jumlah polong isi, hampa dan total polong per tanaman kacang tanah akibat pengaruh pupuk kompos ampas sagu dan PGPR pada berbagai umur pengamatan

\begin{tabular}{lccc}
\hline Perlakuan & $\begin{array}{c}\text { Jumlah polong isi } \\
\text { per tanaman }\end{array}$ & $\begin{array}{c}\text { Jumlah polong } \\
\text { hampa per tanaman }\end{array}$ & $\begin{array}{c}\text { Jumlah total } \\
\text { polong per } \\
\text { tanaman }\end{array}$ \\
\hline Kompos ampas sagu & $15,52 \mathrm{a}$ & $6,63 \mathrm{c}$ & $22,15 \mathrm{a}$ \\
$\mathrm{K}_{0}(\mathrm{kontrol})$ & $16,31 \mathrm{ab}$ & $6,41 \mathrm{bc}$ & $22,72 \mathrm{a}$ \\
$\mathrm{K}_{1}\left(10 \mathrm{t} \mathrm{ha}^{-1}\right)$ & $17,79 \mathrm{bc}$ & $5,88 \mathrm{ab}$ & $23,68 \mathrm{ab}$ \\
$\mathrm{K}_{2}\left(15 \mathrm{t} \mathrm{ha}^{-1}\right)$ & $19,37 \mathrm{c}$ & $5,65 \mathrm{a}$ & $25,02 \mathrm{~b}$ \\
$\mathrm{~K}_{3}\left(20 \mathrm{t} \mathrm{ha}^{-1}\right)$ & 1,61 & 0,73 & 1,66 \\
\hline BNT $5 \%$ & $14,91 \mathrm{a}$ & $6,80 \mathrm{~b}$ & $21,72 \mathrm{a}$ \\
\hline Konsentrasi PGPR & $17,19 \mathrm{~b}$ & $6,09 \mathrm{ab}$ & $23,28 \mathrm{ab}$ \\
$\mathrm{P}_{0}(\mathrm{kontrol})$ & $18,05 \mathrm{bc}$ & $5,98 \mathrm{a}$ & $24,03 \mathrm{~b}$ \\
$\mathrm{P}_{1}\left(5 \mathrm{ml} \mathrm{l}^{-1}\right)$ & $18,85 \mathrm{c}$ & $5,70 \mathrm{a}$ & $24,54 \mathrm{~b}$ \\
$\mathrm{P}_{2}\left(10 \mathrm{ml} \mathrm{l}^{-1}\right)$ & 1,61 & 0,73 & 1,66 \\
$\mathrm{P}_{3}\left(15 \mathrm{ml} \mathrm{l}^{-1}\right)$ & $\mathrm{BNT} 5 \%$ & &
\end{tabular}

Keterangan : Bilangan pada kolom yang sama dan didampingi dengan huruf yang sama pula menunjukkan tidak berbeda nyata pada uji BNT 5\%.

Perlakuan PGPR $\quad\left(\mathrm{P}_{0}\right)$ menghasilkan jumlah polong isi lebih rendah dan polong hampa lebih tinggi dibandingkan tanaman yang diperlakukan PGPR, dengan jumlah polong isi 15,52 dan jumlah polong hampa 6,63 per tanaman. Perlakuan PGPR meningkatkan jumlah polong isi dan menurunkan jumlah polong hampa per tanaman. Perlakuan PGPR dengan konsentrasi 10 dan $15 \mathrm{ml} \mathrm{l}^{-1}\left(\mathrm{P}_{2}\right.$ dan $\left.\mathrm{P}_{3}\right)$ menghasilkan jumlah polong isi lebih tinggi sebesar 18,05 dan 18,85 dan jumlah polong hampa lebih rendah yaitu 5,98 dan 5,70 per tanaman. Jumlah polong total per tanaman pada kacang tanah yang diperlakukan PGPR pada berbagai konsentrasi lebih tinggi $\left(\mathrm{P}_{1}, \mathrm{P}_{2}\right.$ dan $\left.\mathrm{P}_{3}\right)$ dibandingkan tanpa perlakuan PGPR $\left(\mathrm{P}_{0}\right)$. Rata-rata jumlah polong per tanaman kacang tanah yang diperlakukan PGPR berkisar 23,28 - 24,54, sementara tanpa aplikasi PGPR $\left(\mathrm{P}_{0}\right)$ mempunyai jumlah polong total sebesar 21,72.

Perlakuan pupuk kompos ampas sagu pada berbagai dosis meningkatkan bobot polong per tanaman. Tidak terjadi perbedaan nyata diantara ketiga dosis kompos ampas sagu pada peningkatan bobot polong kacang tanah per tanaman.

Pada Tabel 5 menunjukkan bahwa semakin tinggi dosis pupuk kompos ampas sagu yang diberikan semakin meningkatkan bobot biji kacang tanah per tanaman dan per hektar. Bobot biji kacang tanah per tanaman dan per hektar tertinggi diperoleh melalui perlakuan pupuk kompos ampas sagu dengan dosis $20 \mathrm{t} \mathrm{ha}^{-1}\left(\mathrm{~K}_{3}\right)$ dengan hasil biji per tanaman dan per hektar masingmasing sebesar 17,51 g dan 2,80 $\mathrm{t} \mathrm{ha}^{-1}$. Tanaman kacang tanah yang tidak diberikan pupuk kompos ampas sagu $\left(\mathrm{K}_{0}\right)$ menghasilkan bobot biji per tanaman dan per hektar terendah yaitu sebesar 11,51 g dan 1,84 $\mathrm{t} \mathrm{ha}^{-1}$. Pada bobot 100 biji kacang tanah, perlakuan pupuk kompos ampas sagu sebesar $20 \mathrm{t}$ ha $^{-1}\left(K_{3}\right)$ menghasilkan bobot 100 biji lebih besar yaitu 40,14 g, tetapi tidak berbeda nyata dengan perlakuan dengan dosis $15 \mathrm{t} \mathrm{ha}^{-1}\left(\mathrm{~K}_{2}\right)$ yang mempunyai 
S. Adam, M. D.Magfoer dan D.Haryono/ Buana Sains Vol 18 No 1 : 11-20

bobot 100 biji sebesar 39,23 g. Sementara tanaman kacang tanah yang tidak diaplikasikan pupuk kompos ampas sagu $\left(\mathrm{K}_{0}\right)$ menghasilkan bobot 100 biji kacang tanah terendah yaitu sebesar 32,09 $\mathrm{g}$.

Pada Tabel 5 menunjukkan bahwa tanaman kacang tanah yang diperlakukan PGPR dengan konsentrasi 10 dan $15 \mathrm{ml}$ $1^{-1}\left(\mathrm{P}_{2}\right.$ dan $\left.\mathrm{P}_{3}\right)$ mempunyai bobot polong, bobot biji per tanaman dan per hektar lebih tinggi dibandingkan perlakuan lainnya. Hasil biji per hektar pada perlakuan PGPR dengan konsentrasi 10 dan $15 \mathrm{ml} \mathrm{l}^{-1}\left(\mathrm{P}_{2}\right.$ dan $\left.\mathrm{P}_{3}\right)$ masing-masing sebesar 2,47 dan 2,69 $\mathrm{t} \mathrm{ha}^{-1}$. Tanaman kacang tanah yang tidak diperlakukan PGPR $\left(\mathrm{P}_{0}\right)$ mempunyai bobot polong per tanaman lebih rendah dan tidak berbeda dengan perlakuan PGPR dengan konsentrasi $5 \mathrm{ml} \mathrm{l}^{-1}\left(\mathrm{P}_{1}\right)$. Pada bobot biji, tanaman kacang tanah yang tidak diperlakukan PGPR $\left(\mathrm{P}_{0}\right)$ mempunyai bobot biji per tanaman dan per hektar terendah yaitu sebesar 11,51 g per tanaman dan 1,84 ton ha ${ }^{-1}$. Pada bobot 100 biji, peningkatan konsentrasi PGPR menjadi $15 \mathrm{ml} \mathrm{l}^{-1}\left(\mathrm{P}_{3}\right)$ menghasilkan bobot 100 biji lebih tinggi yaitu sebesar
39,48 g, akan tetapi tidak berbeda nyata dengan konsentrasi $10 \mathrm{ml} \mathrm{l}^{-1}\left(\mathrm{P}_{2}\right)$ yang sebesar 37,79 g.

Peningkatan hasil tersebut diduga karena aplikasi PGPR meningkatkan ketersediaan $\mathrm{N}$ dan $\mathrm{P}$ dalam tanah. Hasil analisa tanah sesudah penelitian menunjukkan bahwa terjadi peningkatan $P$ dalam tanah akibat inokulasi mikroorganisme PGPR. Keberadaan mikroba pelarut fosfat dalam PGPR yaitu Aspergillus, Pseudomonas dan Bacillus mampu meningkatkan ketersediaan $\mathrm{P}$ bagi tanaman kacang tanah. Selain itu bakteri fiksasi $\mathrm{N}$ yang terdapat pada Arotobacter bersama bakteri fiksasi N2 lainnya seperti Rhizobium memainkan peran penting dalam peningkatan hasil kacang karena memproduksi sidephores yang mengatur ketersediaan unsur hara untuk tanaman (Moraditochaee et al., 2014). Hasil tersebut sesuai dengan hasil penelitian Prihastuti dan Radjit (2013) yang menunjukkan bahwa aplikasi mikroba penambat $\mathrm{N}$ non simbiotik, bakteri pelarut $\mathrm{P}$ dan mikroba dekomposer meningkatkan hasil biji sebesar 21,40\% dibandingkan kontrol.

Tabel 5. Rata-rata bobot polong dan bobot biji kacang tanah akibat pengaruh pupuk kompos ampas sagu dan PGPR pada berbagai umur pengamatan

\begin{tabular}{llccc}
\hline Perlakuan & $\begin{array}{c}\text { Bobot polong } \\
\left(\mathrm{g} \mathrm{tan}^{-1}\right)\end{array}$ & $\begin{array}{c}\text { Bobot biji } \\
\left(\mathrm{g} \mathrm{tan}^{-1}\right)\end{array}$ & $\begin{array}{c}\text { Bobot biji } \\
\left(\mathrm{t} \mathrm{ha}^{-1}\right)\end{array}$ & $\begin{array}{c}\text { Bobot } 100 \\
\text { biji }(\mathrm{g})\end{array}$ \\
\hline Kompos ampas sagu & & & & \\
$\mathrm{K}_{0}(\mathrm{kontrol})$ & $43,06 \mathrm{a}$ & $11,51 \mathrm{a}$ & $1,84 \mathrm{a}$ & $32,09 \mathrm{a}$ \\
$\mathrm{K}_{1}\left(10 \mathrm{t} \mathrm{ha}^{-1}\right)$ & $47,61 \mathrm{ab}$ & $14,09 \mathrm{~b}$ & $2,25 \mathrm{~b}$ & $37,23 \mathrm{~b}$ \\
$\mathrm{~K}_{2}\left(15 \mathrm{t} \mathrm{ha}^{-1}\right)$ & $49,99 \mathrm{~b}$ & $14,95 \mathrm{~b}$ & $2,39 \mathrm{~b}$ & $39,23 \mathrm{bc}$ \\
$\mathrm{K}_{3}\left(20 \mathrm{t} \mathrm{ha}^{-1}\right)$ & $51,18 \mathrm{~b}$ & $17,51 \mathrm{c}$ & $2,80 \mathrm{c}$ & $40,14 \mathrm{c}$ \\
\hline BNT $5 \%$ & 5,24 & 1,83 & 0,29 & 2,57 \\
\hline Konsentrasi PGPR & & & & \\
$\mathrm{P}_{0}($ kontrol $)$ & $42,13 \mathrm{a}$ & $11,79 \mathrm{a}$ & $1,89 \mathrm{a}$ & $35,30 \mathrm{a}$ \\
$\mathrm{P}_{1}\left(5 \mathrm{ml} \mathrm{l} \mathrm{l}^{-1}\right)$ & $46,11 \mathrm{ab}$ & $13,99 \mathrm{~b}$ & $2,24 \mathrm{~b}$ & $36,13 \mathrm{a}$ \\
$\mathrm{P}_{2}\left(10 \mathrm{ml} \mathrm{l}^{-1}\right)$ & $50,06 \mathrm{bc}$ & $15,46 \mathrm{bc}$ & $2,47 \mathrm{bc}$ & $37,79 \mathrm{ab}$ \\
$\mathrm{P}_{3}\left(15 \mathrm{ml} \mathrm{l}^{-1}\right)$ & $53,54 \mathrm{c}$ & $16,82 \mathrm{c}$ & $2,69 \mathrm{c}$ & $39,48 \mathrm{~b}$ \\
\hline BNT $5 \%$ & 5,24 & 1,83 & 0,29 & 2,57 \\
\hline
\end{tabular}

Keterangan : Bilangan pada kolom yang sama dan didampingi dengan huruf yang sama pula menunjukkan tidak berbeda nyata pada uji BNT 5\% 
S. Adam, M. D.Magfoer dan D.Haryono/ Buana Sains Vol 18 No 1 : 11-20

\section{Kesimpulan}

Tidak terjadi interaksi nyata antara perlakuan kompos ampas sagu dan PGPR pada semua parameter pertumbuhan dan hasil tanaman kacang tanah. Berbagai dosis kompos ampas sagu dan konsentrasi PGPR berpengaruh nyata pada pertumbuhan, hasil dan komponen hasil tanaman kacang pada semua umur pengamatan. Pemberian kompos ampas sagu mempengaruhi pertumbuhan dan hasil kacang tanah. Pemberian dosis kompos ampas sagu dari $15 \mathrm{t} \mathrm{ha}^{-1}$ dan $20 \mathrm{t} \mathrm{ha}^{-1}$ meningkatkan pertumbuhan dan hasil tanaman kacang tanah. Hasil tanaman kacang tanah tertinggi diperoleh melalui perlakuan kompos ampas sagu dengan dosis sebesar $20 \mathrm{t} \mathrm{ha}^{-1}$, dengan bobot biji per tanaman yang dihasilkan sebesar 17,51 g atau meningkat 52,15\% dibandingkan tanpa pemberian kompos ampas sagu, serta hasil bobot biji per hektar sebesar 2,80 $\mathrm{t} \quad \mathrm{ha}^{-1}$. Inokulasi PGPR meningkatkan pertumbuhan dan hasil kacang tanah. Perlakuan PGPR dengan konsentrasi 10 dan $15 \quad \mathrm{ml}^{-1}$ menghasilkan pertumbuhan tanaman kacang tanah lebih baik. Hasil lebih tinggi diperoleh melalui perlakuan PGPR dengan konsentrasi 10 dan $15 \mathrm{ml} \mathrm{l}^{-1}$ dengan bobot biji masing-masing sebesar 15,46 g dan 16,81 $\mathrm{g} \mathrm{tan}^{-1}$ atau meningkat $31,15 \%$ dan $42,6 \%$ dibandingkan kontrol, sedangkan bobot biji per hektar sebesar masing-masing 2,47 $\mathrm{t} \mathrm{ha}^{-1}$ dan $2,69 \mathrm{t} \mathrm{ha}^{-1}$.

\section{Ucapan Terimakasih}

Ucapan terimakasih disampaikan kepada Prof. Dr. Ir. Moch. Dawam Maghfoer, MS dan Dr. Ir. Didik Haryono, MS selaku ketua komisi pembimbing dan anggota komisi pembimbing, serta Bupati, Wakil Bupati dan Kepala BKD Pemerintah Daerah
Kabupaten Halmahera Timur yang telah merekomendasikan dan membiayai penulis dalam menempuh studi pada program magister pertanian fakultas pertanian universitas brawijaya Malang.

\section{Daftar Pustaka}

Badar, R., Z. Nisa and S. Ibrahim. 2015. Supplementation of $\mathrm{P}$ with Rhizobial Inculants to Improve Growth of Peanut Plants. International Journal of Applied Research. 1 (4) : $19-23$.

Kabir, R., S. Yeasmin., A.K.M.M. Islam and Md.A.R. Sarkar. 2013. Effect of Phosphorus, Calcium and Boron on the Growth and Yield of Groundnut (Arachis bypogaea L.). International Journal of Bio Science and Bio-Technology. 5 (3) $: 51-60$.

Kalay, A.M dan F.W. Wijayanti. 2011. Pengaruh Bokelas dan Pupuk Kandang terhadap Hasil Kacang Tanah (Arachis bypogaea L.). Agrinimal. 1 (1) : 28 - 32.

Kumar, D.S., P.S. Kumar and V. Uthaya. 2014. Influence of Biofertilizer Mixed Flower Waste Vermicompost on the Growth, Yield and Quality of Groundnut (Arachis hypogaea). World Applied Sciences Journal. 31 (10) : 1715 1721.

Murtilaksono, K dan S. Anwar. 2014. Potensi, Kendala dan Strategi Pemanfaatan Lahan Kering dan Kering Masam untuk Pertanian (Padi, Jagung, Kedelai), Peternakan dan Perkebunan dengan Menggunakan Teknologi Tepat Guna dan Spesifik Lokasi. Prosiding Seminar Nasional Lahan Suboptimal 2014, Palembang 26 - 27 September 2014. pp : U4 $1-15$. 
S. Adam, M. D.Magfoer dan D.Haryono/ Buana Sains Vol 18 No 1 : 11-20

Marsono dan P. Sigit. 2000. Pupuk Akar Jenis dan Aplikasinya. Jakarta: Penebar Swadaya.

Moraditochaee, M., E. Azarpour and H.R. Bozorgi. 2014. Response of Peanut (Arachis bypogaea L.) to Their Integrated Biofertilizer, Chemical Nitrogen Fertilizer and Plant Density. Applied Life Sciences. 4 (1) : $105-110$.

Prihastuti. 2007. Peluang dan Tantangan Aplikasi Pupuk Hayati pada Tanaman Kacang-kacangan. Agritek. 15 ( 3 ) : 617-624.

Prihastuti dan B.S. Radjit. 2013. Uji Sinergisme Mikroba dalam Pupuk Hayati Kemasan terhadap Pertumbuhan dan Hasil Kacang Tanah di Lahan Kering Non Masam, Gresik. Agrin. 17 (1) : 38 -48 .

Rahni, N.M dan L. Karimuna. 2014. Pengembangan Bioteknologi Pupuk Hijau Plus Berbasis Vegetasi Sekunder untuk Meningkatkan Produksi Kacang Tanah Lokal pada Lahan Kering Marginal. Jurnal Agroteknos. 4 (2) : $94-100$.

Sabran, I., Y.P. soge dan H.I. Wahyudi. 2015. Pengaruh Pupuk Kandang Ayam Bervariasi Dosis terhadap Pertumbuhan dan Hasil Tanaman Kacang Tanah (Arachis bypogaea L.) pada Entisol Sidera. e-J. Agrotekbis. 3 (3) : 297 - 302.
Saleh,B., H and H. Aminpanah. 2015. Effects of Phosphorus Fertilizer Rate and Pseudomonas fluorescens Strain on Field Pea (Pisum sativum subsp. arvense (L.) Asch.) Growth and Yield. Acta Agriculturae Slovenica. 105 (2) : 213 - 224.

Singh, G.P., P.L. Singh and A.S. Panwar. 2011. Response of Groundnut (Arachis hypogaea) to Biofertilizer, Organic and Inorganic Sources of Nutrient in North East India. Legumes Res. 34 (3) : $196-121$.

Triadiati, R. Nisa dan R. Yoan. 2013. Respon Pertumbuhan Tanaman Kedelai terhadap Bradyrbizobium japonicum Toleran Masam dan Pemberian Pupuk di Tanah Masam. Agron. Indonesia. 41 (1): 24-31.

Utami, S.N dan S. Handayani. 2003. Sifat Kimia Entisol pada Sistem Pertanian Organik. Ilmu Pertanian. 10 (2) : 63 - 69 .

Veeramani, P., K. Subrahmaniyan and V. Ganesaraja. 2012. Organic Manure Management on Groundnut : A Review. Wudpecker Journal of Agricultural Research. 1 (7) : 238 $-243$.

Zaimah, F dan E. Prihastanti. 2012. Uji Penggunaan Kompos Limbah Sagu terhadap Pertumbuhan Tanaman Strawberry (Fragaria vesca L). Buletin Anatomi dan Fisiologi. 20 (1) : 18 - 28. 